\title{
Katyonizasyon İşleminin Havlu Kumaş Ön Terbiyesinde Kullanılabilirliğinin ve Ürün Özelliklerine Etkisinin Araştırılması
}

\author{
Ece KALKANLI ${ }^{1}$, Belkıs ZERVENT ÜNAL ${ }^{* 2}$ \\ ${ }^{1}$ ABECOTTON, Mersin \\ ${ }^{2}$ Çukurova Üniversitesi, Mühendislik Fakültesi, Tekstil Mühendisliği Bölümü, Adana
}

$\ddot{\mathbf{O} z}$

Geliş tarihi: 03.10.2019 Kabul tarihi: 20.12.2019

Çalışma kapsamında, farklı hav çözgü hammadde tipine ve farklı gramaja sahip havlu kumaşlar ağartma işleminin uygulanıp uygulanmama durumuna göre de gruplandırıldıktan sonra farklı konsantrasyonlarda katyonize edilmiştir. İşlem görmüş kumaşların yumuşaklık ve hidrofilite değerleri tespit edilmeye çalışılırken ağartma prosesinin yerine çevreci katyonizasyon işleminin uygulanabilirliği de araştırılmıştır. Uygulanan tüm proseslerin ardından yumuşaklık ve hidrofilite değerleri standartlara uygun olarak test edilmiştir. Sonuç olarak, ağartma işlemi yerine katyonizasyon işleminin uygulanmasının havlu kumaşlara yumuşaklık açısından olumlu katkı sağladığı, hidrofilite açısından da kabul edilebilir seviyelerde sonuçlar elde edildiği saptanmıştır.

Anahtar Kelimeler: Katyonizasyon, Havlu, Hidrofilite, Yumuşaklık

\section{Investigation of the Usability of Cationization Process in Terry Fabric Pretreatment and Determination of the Effect on the Product Properties}

\begin{abstract}
The scope of this study, terry fabrics having different pile warp raw material type and different grammage were categorized in different concentrations after grouping according to the application of bleaching process. While trying to determine the softness and hydrophility values of treated fabrics, the applicability of environmental cationization process instead of bleaching process was investigated. After all processes, softness and hydrophility values were tested according to the standards. As a result, it was found that the application of cationization instead of bleaching process contributed positively to the softness of towel fabrics and acceptable levels were obtained in terms of hydrophility.
\end{abstract}

Keywords: Cationization, Towel, Hydrophility, Softness

*Sorumlu yazar (Corresponding author): Belkıs ZERVENT ÜNAL, belzer@cu.edu.tr 


\section{GíRiş}

Türkiye tekstil sektörü, yoğun ve nitelikli işgücü, standartları yakalayan kaliteli üretim prosesleri, gelişmeleri yakından takip eden tasarımcıları, donanımlı ve modern işletmeleri, çevreci üretim anlayışı sayesinde her geçen gün büyümektedir. Entegre üretim, hızlı teslimat ve jeopolitik konum avantajı ile Türkiye, dünyada en çok tercih edilen tekstil ülkeleri listesinde sürekli yükselmektedir. Tekstil ithalat ve ihracatı açısından önemli bir yere sahip ev tekstili grubunun önemi de gün geçtikçe artarken, bu grubun en önemli ürününü havlular ve havlu kumaşlardan elde edilen ürünler oluşturmaktadır.

Türkiye Ev Tekstili Sanayicileri ve İşadamları Derneği'nin (TETSİAD) güncel verilerini içeren raporuna bakıldığında 2017-2018 Ocak-Haziran döneminde toplam ev tekstili grubunda düşüş tespit edilmesine rağmen havlu ve bornozlar toplam ev tekstili ihracatında \%30'dan fazla payla açık ara birincidir [1].

Havlu kumaşların kullanım yeri nedeniyle sahip olmaları gereken en temel özellikler; yüksek hidrofilite, yumuşaklık, kuruma süresinin kısalığı, kolay ve sik temizlemeye uygunluk, antibakteriyellik ve yüksek renk haslıklarıdır.

Pamuk liflerinin doğal yapılarından kaynaklanan veya üretim esnasında bulaşan safsızlıklar kumaşa hidrofob ve sarımtırak bir renk kazandırdığından bu safsızlıklar ağartma işlemi ile uzaklaştırılmaktadır.

Katyonizasyon işlemi selülozik tekstil elyaflarına ve özellikle pamuklu mamüllere yüzey yükünü değiştirip boyama işlemini kolaylaştırmak için uygulanan bir ön terbiye prosesidir. Katyonizasyon işleminin uygulanmasıyla pamuklu mamullerin boyama verimi artmakta ve boyarmadde banyosundaki atık su daha az kimyasal ve boyarmadde molekülü içermektedir. Çevre dostu ürün ve üretim proseslerinin önem kazandığ günümüz rekabet koşullarında katyonizasyon işleminin prosesleri kısaltması ve maliyetleri düşürmesi yanında atık su problemini de azaltacak olması bu işlemin üretim süreci açısından önemini göstermektedir [2].

Çalışma kapsamında havlu kumaş üretiminde ağartma işlemi yerine katyonizasyon işleminin kullanılabilirliği ve ağartma işlemiyle birlikte yada ağartma işlemi olmadan sadece farklı konsantrasyonlarda uygulanan katyonizasyon işleminin havlu kumaşların önemli özelliklerinden olan yumuşaklık ve hidrofilite değerlerine etkisi araştırılmıştır.

\section{2. ÖNCEKİ ÇALIŞMALAR}

Chattopadhyay, 2001 yılında pamuğun sulu ortamda negatif yük kazandığından yola çıkarak, boyama esnasında boyarmadde-lif etkileşimini irdelemiştir. Chattopadhyay'a göre sulu ortamda negatif yük kazanan pamuk, boyama esnasında negatif yüklü boyarmadde anyonunu püskürtmekte bu nedenle özellikle reaktif boyamalarda fiksajı azaltmakta ve renkli atık suları da çevre sorunu oluşturmaktadır. Chattopadhyay çalışmasında tuz kullanmadan ya da az miktarda tuz kullanılarak pamuğun boyarmadde substantivitesini geliştirmenin katyonizasyon işlemiyle mümkün olduğunu belirtmiştir. Aynı zamanda pamuk içerisinde katyonik alan elde etmek için çevre dostu katyonik ajanların geliştirilmesine ihtiyaç duyulduğunu belirtmiş ve kitin polimerinden elde edilen kitosanı bu yöntem için önermiştir [3].

Srikulkit ve Larpsuriyakul, 2002 yılında çeşitli metotlarla elde ettikleri katyonik ajanları tek bir banyo içerisinde selüloz liflerinin ağartma prosesinde uygulamışlardır. Araştırmacılara göre kullanılan katyonik bileşen ağartma performansını az derecede de olsa olumsuz etkilemiştir. Katyonize edilen ağartılmış pamuklu kumaşlar tuz kullanmadan reaktif boyarmaddelerle boyanmıştır. Katyonize maddesinin konsantrasyonu arttıça boyarmadde alımı ve renk kuvveti artmıştır. Ayrıca katyonizasyon işlemiyle geleneksel boyamalara göre daha düşük boyarmadde konsantrasyonu kullanılmakta ve daha iyi renk verimi elde edilmektedir. Bunun yanısıra katyonizasyon işlemi ağartma prosesiyle birlikte uygulandığından su ve enerji tasarrufu sağlarken, 
işlemde tuz kullanılmadığı için tuzu uzaklaştırma gereksinimi de bulunmamaktadır [4].

Onar, 2006'daki çalışmasında katyonizasyon ön işlemenin enerji ve kimyasal maddeden tasarruf sağlayarak çevre dostu bir uygulama olmasının önemini vurgulamış ve literatürdeki çalışmaları incelemiştir. Çalışmasında katyonize edilmiş pamukların boyanması, baskı prosesi ve bitim işlemlerini ayrı ayrı incelemiştir. Pamuklu kumaşların katyonizasyonunda kullanılan kimyasalları, katyonizasyon işleminin uygulama yöntemlerini ve katyonizasyon işlemi için optimum koşulları araştırmıştır [2].

Oktav ve Dayığlu, 2008'de yapmış oldukları çalışmada katyonik pamuklu kumaşların bakım özellikleri üzerinde durmuşlardır. Katyonizasyon işleminin buruşmazlık ve boyut değişimi üzerine etkilerini araştırmışlardır. Katyonikleştirme işleminde karşılaştıkları mukavemet düşmelerinden dolayı prosesteki kurutma işlemi yerine buharlamayı tercih etmişlerdir. Katyonizasyon işlemi gören numuneler asit boyarmaddeleriyle boyanabilmiştir. Araştırma sonucunda; katyonizasyon işlemiyle pamuklu kumaşlar asit boyarmaddeleriyle boyanabilmiş, boyutsal stabilite ve buruşmazlık derecesinde artış sağlamışlardır. Ürünlerin 1 şık haslığ 1 değerleri yeterli görülmüş bu noktada yapılan önceki çalışmalardan daha farklı bir sonuç elde edilmiştir [5].

Nakpathom ve ark, 2018'de yürüttükleri deneysel çalışmada pamuklu kumaşı öncelikle katyonize edip daha sonra doğal boyarmaddeler ile boyamışlardır. En iyi renk verimi elde ettikleri kimyasal bileşeni ve bu bileşeni uyguladıkları koşulları belirtmişlerdir. Çeşitli kimyasallarla işleme aldıkları pamuklu kumaşların renk ve yıkama haslık değerlerini işlem görmemiş pamuklu kumaşlarla kıyaslamışlardır. İşleme alınan dört farklı kimyasal iki farklı yöntemle uygulanmıştır. Hangi uygulamanın $\mathrm{K} / \mathrm{S}$ değerini geliştirip 1şık haslığ her iki yöntemin yıkama haslığı değerini düşürdüğünü fakat bu değerin kabul edilebilir seviyelerde olduğunu bildirmişlerdir [6].

\section{MATERYAL VE METOT}

\subsection{Materyal}

Çalışma kapsamında, katyonizasyon işleminin havlu kumaşların ön terbiye prosesinde ağartma işlemi yerine kullanılabilirliği ve katyonizasyon işleminin ve bu işlem parametrelerinin kumaş performans özelliklerinden yumuşaklık ve hidrofilite değerleri üzerine etkisinin incelenmesi amaçlanmıştır. $\mathrm{Bu}$ amaçla iki farklı gramaj ve iki farklı hav hammaddesine (\%100 pamuk ve $\% 100$ modal) sahip, diğer tüm özellikleri sabit 4 farklı havlu kumaş üretimi gerçekleştirilmiştir. Ardından aynı kumaşların bir kısmı ağartma işleminden sonra bir kısmı da ağartmasız halde farklı konsantrasyonda katyonizasyon işlemine tabi tutulmuştur. Çalışmada kullanılan tüm havlu kumaşların fiziksel özellikleri aynı olup (hav çözgü iplik numarası Ne16/1, zemin çözgü iplik numaras1 Ne 20/2, atk1 iplik numarası Ne 12/1), gramaj farklılığı sadece atkı sıklığı değiştirilerek elde edilmiştir [7].

Çizelge 1. Ham havlu numunelerinin fiziksel özellikleri

\begin{tabular}{|c|c|c|c|c|}
\hline $\begin{array}{c}\text { Numune } \\
\text { Kodu }\end{array}$ & $\begin{array}{c}\text { Hav } \\
\text { Tipi }\end{array}$ & $\begin{array}{c}\text { Gramaj } \\
\left(\mathbf{g} / \mathbf{m}^{2}\right)\end{array}$ & $\begin{array}{c}\text { Çözgü } \\
\text { Sıklığı } \\
(\text { tel/cm) }\end{array}$ & $\begin{array}{c}\text { Atkı } \\
\text { Sıklı̆̆ } \\
(\text { tel/cm) }\end{array}$ \\
\hline M1 & $\begin{array}{c}\% 100 \\
\text { Modal }\end{array}$ & 340 & 14 & 14 \\
\hline M2 & $\begin{array}{c}\% 100 \\
\text { Modal }\end{array}$ & 430 & 14 & 19 \\
\hline P1 & $\begin{array}{c}\% 100 \\
\text { Pamuk }\end{array}$ & 340 & 14 & 14 \\
\hline P2 & $\begin{array}{c}\% 100 \\
\text { Pamuk }\end{array}$ & 430 & 14 & 19 \\
\hline
\end{tabular}

Çalışma kapsamında, dokunmuş ve haşıl sökümü işlemi uygulanmış olan numunelerin birer parçasına ağartma işlemi uygulanmıştır. Katyonizasyon işleminin ve farklı katyonizasyon oranlarının havlu özelliklerine etkisini belirlemek için hem ağartılmış hem de ağartılmamış kumaşlara katyonizasyon işlemi uygulanmıştır. Çizelge 2'de ağartma ve/veya katyonizasyon işlemi uygulanmış numunelerin dağılımı görülmektedir. Katyonizasyon oranı $\% 0$ görünen numunelere söz konusu işlem uygulanmamıştır. 
Böylelikle farklı yapıdaki 4 ham havlu numunesinden farklı terbiye işlemleri uygulanarak 20 farklı numune türetilmiştir.

Çizelge 2. Numunelere uygulanan ön terbiye işlemleri deney planı

\begin{tabular}{|c|c|c|}
\hline $\begin{array}{c}\text { Numune } \\
\text { Kodu }\end{array}$ & $\begin{array}{l}\text { Ağartma } \\
\text { Durumu }\end{array}$ & $\begin{array}{l}\text { Katyonize } \\
\text { Oranı }(\%) \\
\end{array}$ \\
\hline \multirow{5}{*}{ M1 } & \multirow{2}{*}{ Ağartmasız } & 3 \\
\hline & & 9 \\
\hline & \multirow{3}{*}{ Ağartmalı } & 0 \\
\hline & & 3 \\
\hline & & 9 \\
\hline \multirow{5}{*}{ M2 } & \multirow{2}{*}{ Ağartmasız } & 3 \\
\hline & & 9 \\
\hline & \multirow{3}{*}{ Ağartmalı } & 0 \\
\hline & & 3 \\
\hline & & 9 \\
\hline \multirow{5}{*}{ P1 } & \multirow{2}{*}{ Ağartmasız } & 3 \\
\hline & & 9 \\
\hline & \multirow{3}{*}{ Ağartmalı } & 0 \\
\hline & & 3 \\
\hline & & 9 \\
\hline \multirow{5}{*}{$\mathrm{P} 2$} & \multirow{2}{*}{ Ağartmasız } & 3 \\
\hline & & 9 \\
\hline & \multirow{3}{*}{ Ağartmalı } & 0 \\
\hline & & 3 \\
\hline & & 9 \\
\hline
\end{tabular}

Ağartma işlemi uygulanmamış kumaşlar \%3 ve $\% 9$ oranlarında katyonize işlemine tabi tutulmuş olup çalışma kapsamında ağartma ve katyonize işlemleri uygulanmamış numune kumaş grubu bulunmamaktadır. Ancak ağartma işlemi uygulanmış fakat katyonize edilmemiş kumaşlar çalışmaya dahil edilmiştir.

Katyonizasyon ajanı olarak Affinitas ALK kullanılmıştır. Katyonizasyon prosesi ağartma işlemi ile aynı flotte oranında, aynı metot ve aynı makinede gerçekleştirilmiştir. $25^{\circ} \mathrm{C}$ 'de 10 dakika işlem gören kumaşların sıcaklığı $60{ }^{\circ} \mathrm{C}^{\prime}$ ye kadar yükseltilmiş ve 30 dakika beklenmiştir. Katyonizasyon oranına göre belirlenen katyonizasyon ajanı banyoya $25{ }^{\circ} \mathrm{C}$ 'de verilirken, banyo sıcaklığg $60{ }^{\circ} \mathrm{C}$ 'ye ulaştığında kostik ilave edilmiştir. İşlem tamamlandığında $25{ }^{\circ} \mathrm{C}$ 'de 10 dakika boyunca soğuk durulama işlemi uygulanmış ve banyo boşaltılmıştır.

\subsection{Metod}

\subsubsection{Yumuşaklık Derecesinin Tayini}

Numune havlu kumaşların yumuşaklık derecesini belirlemek için Dijital Pnömatik Stiffnes Tester cihazı kullanılmıştır. ASTM (American Society for Testing and Materials) D 4032-94 Dairesel Eğme Test Metodu esas alınmıştır [8].

\subsubsection{Hidrofilite Derecesinin Tayini}

Havlu kumaşların hidrofilite derecelerini belirlemek amacıyla TS EN 14697 standardına göre belirlenen sayıda ve ölçüde alt numuneler hazırlanmış ve batma testi uygulanmıştır [9]. Ölçümü yapılan numune havlu kumaşların batma süreleri saniye cinsinden kaydedilmiştir.

\section{BULGULAR VE TARTIŞMA}

\subsection{Yumuşaklık Testi Sonuçları}

Stiffness test cihazı ile yapılan yumuşaklık testinin ölçüm sonuçları Çizelge 3'de verilmiştir. Deneysel olarak tespit edilen yumuşaklık değerlerinin seçilmiş parametrelere göre irdelenmesi amacıyla oluşturulan grafikler Şekil 1'de görülmektedir.

Çizelge 3. Yumuşaklık testi sonuçları

\begin{tabular}{|c|c|c|c|}
\hline $\begin{array}{l}\text { Numune } \\
\text { Kodu }\end{array}$ & $\begin{array}{l}\text { Ağartma } \\
\text { Durumu }\end{array}$ & $\begin{array}{l}\text { Katyonize } \\
\text { Oranı }(\%)\end{array}$ & $\begin{array}{l}\text { Yumuşaklık } \\
\text { Değeri (kg) }\end{array}$ \\
\hline \multirow{5}{*}{ M1 } & \multirow{2}{*}{ Ağartmasız } & 3 & 0,219 \\
\hline & & 9 & 0,174 \\
\hline & \multirow{3}{*}{ Ağartmalı } & 0 & 0,327 \\
\hline & & 3 & 0,355 \\
\hline & & 9 & 0,333 \\
\hline \multirow{5}{*}{ M2 } & \multirow{2}{*}{ A ğartmasız } & 3 & 0,405 \\
\hline & & 9 & 0,429 \\
\hline & \multirow{3}{*}{ Ağartmalı } & 0 & 0,559 \\
\hline & & 3 & 0,622 \\
\hline & & 9 & 0,670 \\
\hline \multirow{5}{*}{$\mathrm{P} 1$} & \multirow{2}{*}{ A ğartmasız } & 3 & 0,233 \\
\hline & & 9 & 0,200 \\
\hline & \multirow{3}{*}{ Ağartmalı } & 0 & 0,377 \\
\hline & & 3 & 0,356 \\
\hline & & 9 & 0,361 \\
\hline \multirow{5}{*}{$\mathrm{P} 2$} & \multirow{2}{*}{ Ağartmasız } & 3 & 0,398 \\
\hline & & 9 & 0,433 \\
\hline & \multirow{3}{*}{ Ağartmalı } & 0 & 0,801 \\
\hline & & 3 & 0,806 \\
\hline & & 9 & 0,856 \\
\hline
\end{tabular}




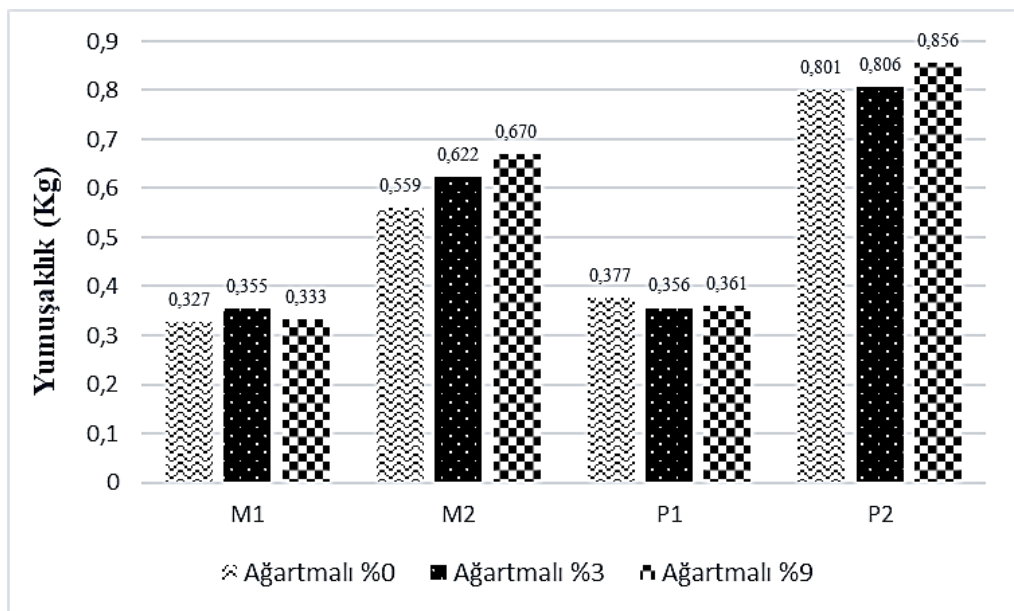

(a)Yumuşaklık Değerleri-(Ağartmalı numuneler)

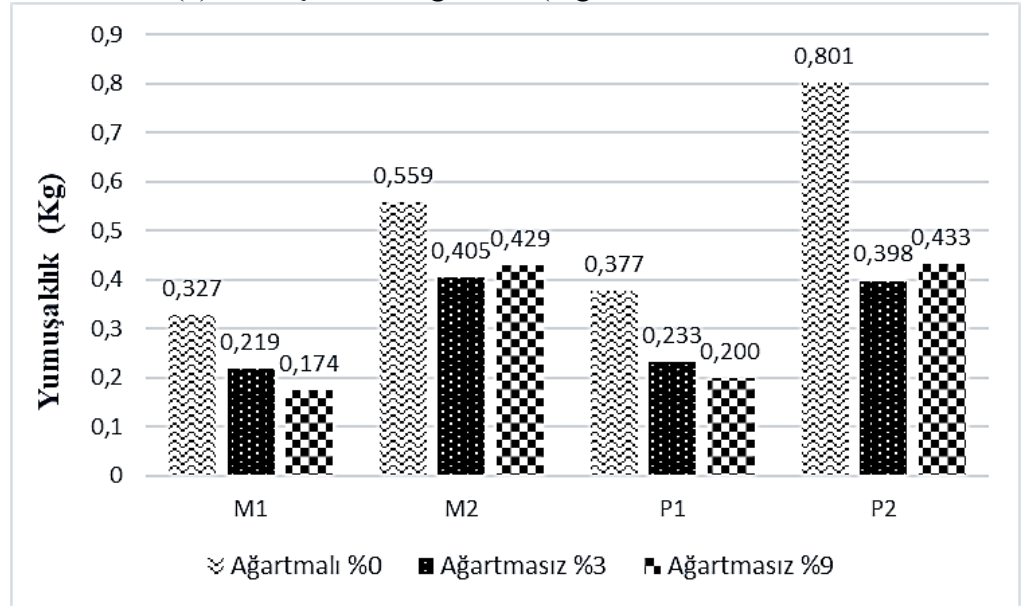

(b)Yumuşaklık Değerleri-(Ağartmasız numuneler)

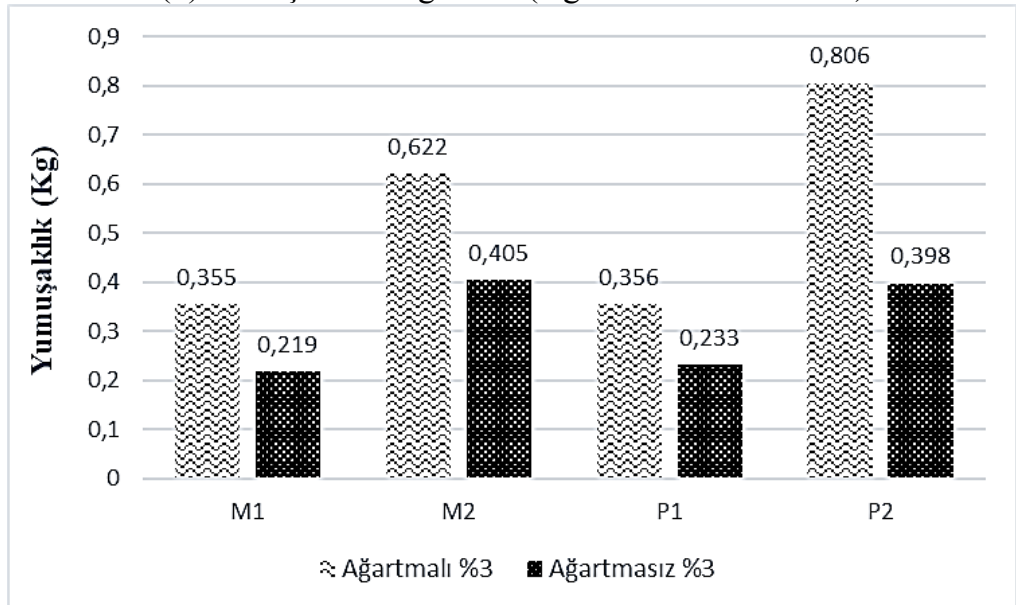

(c)Yumuşaklık Değerleri-(\%3 Katyonizasyon oranı) 


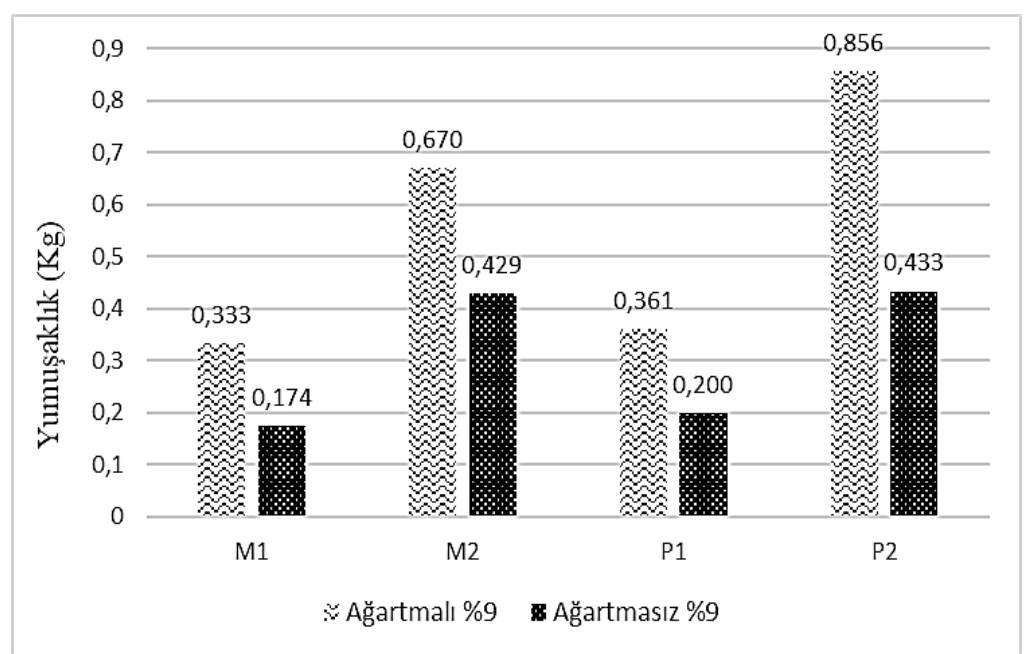

(d)Yumuşaklık Değerleri-(\%9 Katyonizasyon oranı)

Şekil 1. Ağartma durumu ve katyonizasyon oranının yumuşaklık değerlerine etkisi

Şekil 1(a) da görüldüğü gibi ağartma uygulanmış kumaşlarda katyonizasyon işleminin uygulanması yumuşaklık üzerinde önemli bir etkiye sahip olmamıştır. Ancak Şekil 1(b) incelendiğinde sadece ağartma uygulanmış kumaşların yumuşaklık değerlerinin ağartmasız kumaşların yumuşaklık değerlerinden daha yüksek olduğu başka bir ifadeyle kumaşın daha sert olduğu görülmektedir. $\mathrm{Bu}$ nedenle yumuşaklık açısından değerlendirildiğinde ağartma işlemi yerine katyonizasyon işleminin havlu kumaş üretiminde uygulanması kumaş performansı açısından daha avantajlı görünmektedir.

Ancak katyonizasyon oranının havlu yumuşaklığı üzerinde anlamlı bir etkisinin olduğu söylenememektedir. Şekil 1(c) ve (d)'de görüldüğü gibi katyonizasyon işlemi uygulanmış olan havlularda ağartma işlemi hem \%3 hem de \%9 konsantrasyonda yumuşaklık değerinin yükselmesine başka bir ifadeyle numunenin sertleşmesine yol açmıştır. Bu durum hem pamuk hem de modal hammaddeli numuneler için geçerli olmuştur.

\subsection{Hidrofilite Testi Sonuçları}

Çalışma kapsamında numune kumaşlara uygulanan hidrofilite testi sonuçları Çizelge 4'te verilmiştir. Bu sonuçlar kullanılarak oluşturulan grafikler ise Şekil 2'de verilmiştir. Batma testi sonucu elde edilen değer arttıkça kumaşın hidrofilitesinin düştüğ̈̈/azaldığı (suyun daha geç emildiği) anlaşılmaktadır.

Çizelge 4. Hidrofilite testi sonuçları

\begin{tabular}{|c|c|c|c|}
\hline $\begin{array}{c}\text { Numune } \\
\text { Kodu }\end{array}$ & $\begin{array}{l}\text { Ağartma } \\
\text { Durumu }\end{array}$ & $\begin{array}{l}\text { Katyonize } \\
\text { Oranı (\%) } \\
\end{array}$ & $\begin{array}{l}\text { Hidrofilite } \\
\text { Değeri (sn) }\end{array}$ \\
\hline \multirow{5}{*}{ M1 } & \multirow{2}{*}{ A ğartmasız } & 3 & 17,73 \\
\hline & & 9 & 25,13 \\
\hline & \multirow{3}{*}{ Ağartmalı } & 0 & 1,00 \\
\hline & & 3 & 1,37 \\
\hline & & 9 & 3,78 \\
\hline \multirow{5}{*}{ M2 } & \multirow{2}{*}{ Ağartmasız } & 3 & 89,25 \\
\hline & & 9 & 244,00 \\
\hline & \multirow{3}{*}{ Ağartmalı } & 0 & 1,17 \\
\hline & & 3 & 1,73 \\
\hline & & 9 & 3,27 \\
\hline \multirow{5}{*}{ P1 } & \multirow{2}{*}{ Ağartmasız } & 3 & 12,05 \\
\hline & & 9 & 26,13 \\
\hline & \multirow{3}{*}{ Ağartmalı } & 0 & 1,37 \\
\hline & & 3 & 1,10 \\
\hline & & 9 & 1,17 \\
\hline \multirow{5}{*}{$\mathrm{P} 2$} & \multirow{2}{*}{ Ağartmasız } & 3 & 65,48 \\
\hline & & 9 & 42,72 \\
\hline & \multirow{3}{*}{ Ağartmalı } & 0 & 1,17 \\
\hline & & 3 & 1,13 \\
\hline & & 9 & 1,77 \\
\hline
\end{tabular}




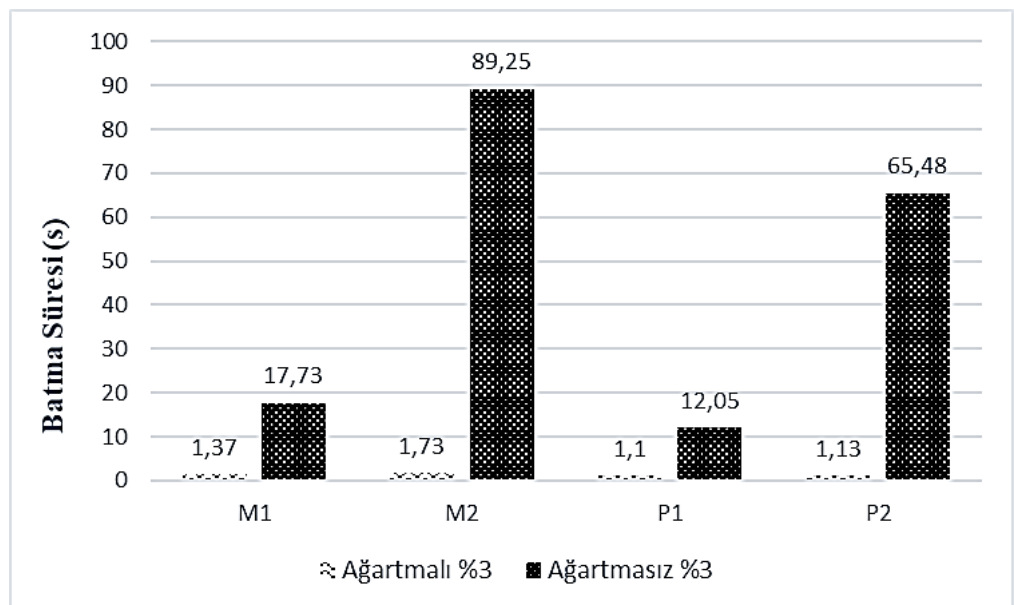

(a) Hidrofilite Değerleri-(\%3 Katyonizasyon oranı)

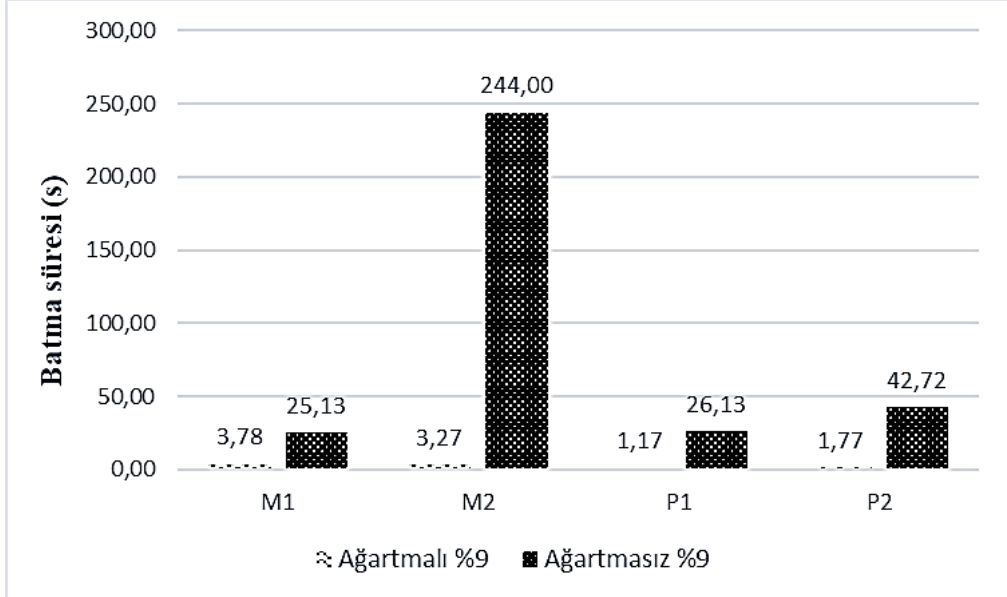

(b) Hidrofilite Değerleri-(\%9 Katyonizasyon oran1)

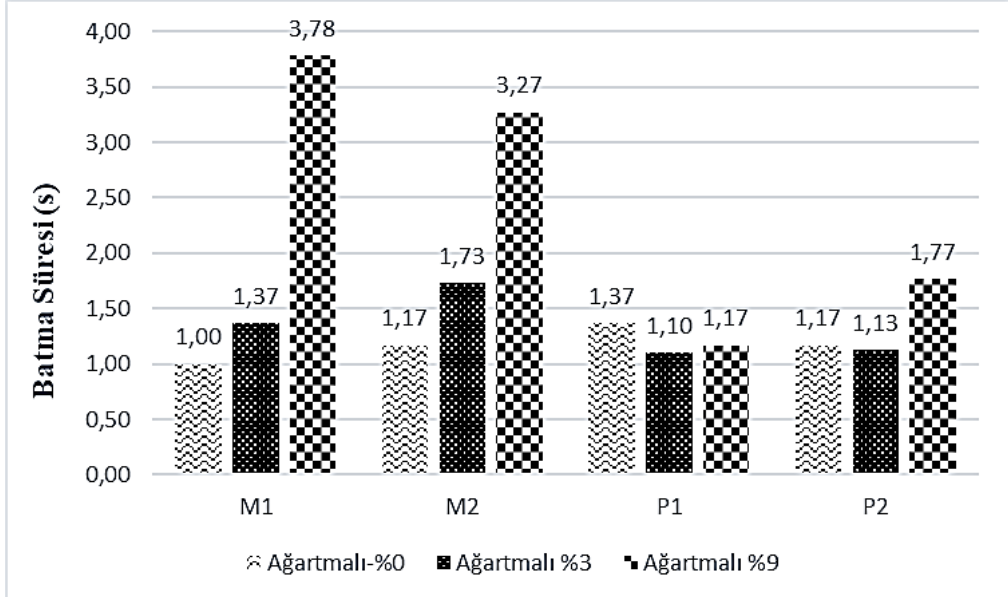

(c) Hidrofilite Değerleri-(A ğartmalı numuneler) 


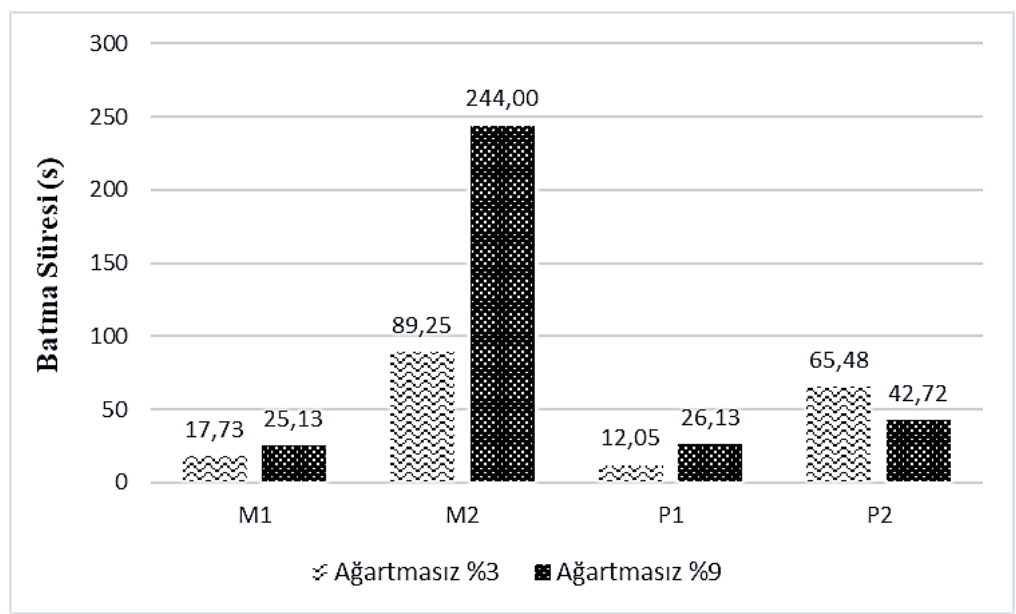

(d) Hidrofilite Değerleri-(Ağartmasız numuneler)

Şekil 2. Ağartma durumu ve katyonizasyon oranının hidrofilite değerlerine etkisi

Çizelge ve grafiklerden görüldüğü üzere ağartmalı numunelerin hidrofilite değerleri katyonizasyon işlemi uygulansa da uygulanmasa da ağartmasız kumaşlarda oldukça düşük çıkmıştır. Başka bir ifadeyle bu kumaşların hidrofilitelerinin daha iyi olduğu söylenebilmektedir. Bu durumda ağartma işleminin hidrofilite açısından katyonizasyon işlemine göre daha avantajlı olduğu söylenebilmektedir. Ancak ağartmasız numunelere katyonizasyon uygulandığında elde edilen hidrofilite değerlerinin, M2 kodlu numune dişında kabul edilebilir sınırlar içinde olduğu görülmektedir. Havlu kumaşlarda batma testi sonucu hidrofilite değerinin işletme şartlarında ve kullanımda en fazla 100 saniye olması istenmektedir. $\mathrm{Bu}$ nedenle havlu üretim prosesinde ağartma yerine katyonizasyon işleminin kullanılmasının yumuşaklığın aksine hidrofiliteyi bir miktar düşürdüğü ancak elde edilen değerlerin kullanım yerine göre kabul edilebilir sınırlar içinde olduğu söylenebilmektedir.

\section{SONUÇLAR}

Çalışma kapsamında pamuk ve modal hav hammaddeli havlu kumaşların ön terbiyesinde katyonizasyon işleminin uygulanabilirliği ve katyonizasyon oranının havlu performansına etkisinin irdelenmesi amaçlanmış olup, elde edilen sonuçlardan seçilmiş olanlar aşağıda özetlenmiştir.

- Havlu kumaşlarda ağartma işlemi yerine katyonizasyon işleminin uygulanabildiği ve katyonizasyon görmüş kumaşlarda tuz ve soda kullanmadan boyama işlemi gerçekleştirilebildiği görülmüştür.

- Açık ve parlak renkler dişında kalan boyamalar için ağartma mutlaka olması gereken bir adım değildir. Fakat iyi bir hidrofiliteye sahip olunması ve boyama prosesinin başarısı açısından oldukça önemlidir. Açık renklerin boyanması için iyi bir ağartma yapılması gereklidir. Bu durumda sadece katyonizasyon işleminin uygulanmasiyla yeterli hidrofilite elde edildiğinde koyu renk boyamalarda ağartma uygulanmadan sadece katyonizasyon işlemiyle yeterli bir boyama işlemi gerçekleştirilebilir.

- Ağartma işlemi yerine katyonizasyon işleminin havlu kumaşa uygulanmasının yumuşaklık değerini iyileştirdiği tespit edilmiştir.

- Ağartma işlemi uygulanmış kumaşlara hangi oranda katyonizasyon işlemi uygulanırsa uygulansın yumuşaklık değerini yükselttiği (kumaşın sertleştiği) tespit edilmiştir.

- Katyonizasyon konsantrasyonunun 
yumuşaklık değeri üzerinde anlamlı bir etkisi saptanmamıştır.

- Ağartma işlemi yerine katyonizasyon işleminin uygulanması hidrofiliteyi bir miktar düşürse de bu değerin kullanım yerine göre kabul edilebilir seviyede olduğu saptanmıştır.

- Katyonizasyon işleminden bağımsız olarak ağartma işlemi uygulanmasının batma süresini kısalttığı saptanmıştır.

- Katyonizasyon oranının değişmesinin hidrofilite üzerinde anlamlı bir etkisi olmadığı tespit edilmiştir.

Sonuç olarak havlu kumaş üretiminde hav çözgüsü, atkı ve zemin çözgüsü hammaddesi olarak \%100 pamuk kullanılması durumunda ön terbiye prosesinde ağartma yerine daha çevreci ve daha düşük maliyetli katyonizasyon işleminin kullanılabileceği görülmüştür. Ancak aynı durum, hidrofilitedeki kötüleşme nedeniyle hav hammaddesi \%100 modal olan ağır gramajlı numune grubu için sözkonusu olamamıştır.

\section{TEŞEKKÜR}

Çalışma kapsamında numune kumaşların üretimi ile ilgili olarak gösterdikleri katkı ve yardımlar için Hateks Hatay Tekstil İşletmelerine ve Türk Tekstil Vakfi Mesleki ve Teknik Eğitim Merkezi'ne teşekkür ederiz.

\section{KAYNAKLAR}

1. http://www.tetsiad.org/files/raporlar/ocak haziran.pdf, (Erişim tarihi: Mayıs 2019)

2. Onar, N., 2006. Katyonik Pamuk Eldesi ve Uygulamalar1. The Journal of Textiles and Engineer, İzmir, 61, 33-40.

3. Chattopadhy, D.P., 2001. Cationization of Cotton for Low-Salt or Salt-Free Dyeing.Indian Journal of Fibre \& Textile Research, India, 26, 108-115.

4. Srikulkit, K., Larpsuriyakul, P., 2002. Process of Dyeability Modification and Bleaching of Cotton in a Single Bath. Coloration Technology, Colume, 118(2), 79-84.

5. Oktav, M., Dayığlu, H., 2008. Pamuklu Mamullerin İyonik Modifikasyon Yardımıyla
Kolay Bakım Özelliklerinin İncelenmesi. Tekstil ve Mühendis, 70-71, 17-31.

6. Nakpathom, M., Somboon, B., Narumol, N., Mongkholrattanasit R., 2018. Dyeing of Cationized Cotton with Natural Colorant from Purple Corncob, Journal of Natural Fibers, 15(5), 668-679.

7. Kalkanl, E., 2019. Havlu Kumaşlara Katyonizasyon İşleminin Uygulanması ve Söz Konusu İşlemin Ürün Performansına Etkisinin İncelenmesi. Çukurova Üniversitesi, Fen Bilimleri Enstitüsü, Tekstil Mühendisliği Bölümü, Yüksek Lisans Tezi, Adana.

8. ASTM D 4032: 1994 Standard Test Method for Stiffness of Fabric by the Circular Bend Procedure (Dairesel Eğme Test Metodu).

9. TS EN 14697-Tekstil-Havlular ve Havlu Kumaşlar-Özellikler ve Deney Metodları, 2007. 
